Reprod. Nutr. Dévelop., 1981, 21 (5A), 611-620.

\title{
The effect of restricted food intake and refeeding on the ovarian follicle population of the pre-puberal Wistar rat
}

\author{
par Sue LINTERN-MOORE ( $\left.{ }^{1}\right)$, A. V. EVERITT*, J.-C. MARIANA**, P. MAULÉON** \\ Physiologie animale, I.N.R.A. \\ 78350 jouy en Josas, France \\ * Dept. of Physiology, University of Sydney \\ Sydney, NSW 2006 Australia \\ ** Physiologie de la Reproduction, I.N.R.A. \\ Nouzilly 37380 Monnaie, France.
}

Summary. A 50 p. 100 restriction of food intake in female Wistar rats from day 21 to day 42 of life prevented ovulation and altered the size distribution and numbers of ovarian follicles. The rate of atresia of non-growing oocytes in primordial follicles was retarded resulting in more oocytes per ovary. The number of follicles initiated to grow was reduced.

Semi-starved rats allowed free access to food from day 42 of life achieved the body weight of ad libitum-fed controls at 66 days of age. A delayed puberty occurred. The numbers of non-growing oocytes in primordial follicles per ovary declined but remained significantly greater than control values at 66 days of age. Refeeding increased the numbers of follicles undergoing growth but within the size distribution found in age-matched controls. Thus semi-starvation followed by refeeding rendered the ovary developmentally younger but only in terms of total oocyte numbers.

The ovarian response to starvation and refeeding is discussed in relation to pituitary function and provides new information on the potential lability of the oocyte population.

\section{Introduction.}

The inhibition of reproductive function by semi-starvation and its restoration by refeeding is an incontestable fact in all mammals studied (Lamming, 1966). However, little attention has been paid to the effects of starvation and refeeding on the ovarian follicle population beyond the presence or absence of vesicular follicles and corpora lutea (Dickerson ef al., 1964 ; Widdowson ef al., 1964).

In the mammalian ovary the numbers of oocytes present are limited early in life and decline with age due to cell death in the non-growing pool of primordial follicles and during follicular growth towards ovulation (Zuckerman, 1951 ; Mauléon, 1969 ; Peters, 1969). The degree of dependence, if any, of the non-growing oocyte (primordial follicle) population on pituitary function is unknown. Whilst efforts to alter the numbers

(1) Present address to which all correspondence should be sent : Dept. of Zoology, University of Adelaide, Adelaide, 5000 South Australia, Australia. 
of primordial follicles with exogenous gonadotrophins have proved unsuccessful (see Lintern-Moore, 1978a), removal of the pituitary gland retards but does not prevent the atresia of the non growing oocyte population (Jones and Krohn, 1961). Recently we have shown that a reduced food intake, which is known to depress pituitary function (Everitt and Porter, 1976), also retards the age dependent loss of non growing oocytes from the rat ovary (Lintern-Moore and Everitt, 1978). Although oocyte depletion is never ghe cause of senile sterility in the rat (Aschheim, 1976), an extension of reproductive life after semi-starvation has been reported (Visscher et al., 1952 ; Berg, 1960 ; Holeckova and Chvapil, 1965).

The purpose of the present study was to examine the effects of restoration of body weight and reproductive function on the size distribution and number of ovarian follicles in semi-starved rats. We report that refeeding after a period of food restriction does not reduce total oocyte numbers to values recorded in weight-matched controls of the same chronological age, but the relative size distribution of follicles is restored to control values.

\section{Materials and methods.}

Twenty-eight female Wistar strain rats which were not littermates were weaned at 21 days of age and caged individually in an air conditioned room at $25^{\circ} \mathrm{C}(12 \mathrm{~h} \mathrm{light:}$ $12 \mathrm{~h}$ dark). Fourteen rats received commercial pelletted food and water ad libifum (control groups). The remaining 14 rats received a limited ration averaging $6.5 \mathrm{~g}$ of commercial pelletted food per day, which is about 50 p. 100 of the ad libitum food intake.

Rats were weighed at regular intervals throughout the experiment and inspected for vaginal opening. At 42 days of age, 6 starved $(S)$ and 6 control rats $\left(C_{1}\right)$ were killed by cervical dislocation. The remaining 8 starved rats were then allowed ad libitum food intake until body weight reached control values (SR). This occurred at 66 days of age when the remaining 8 starved/refed and 8 control rats $\left(C_{2}\right)$ were killed.

At both 42 days and 66 days of age the ovaries and uteri of all animals were removed, weighed and fixed in Bouin's aqueous fixative. Ovaries were embedded in paraffin wax, serially sectioned at $8 \mu \mathrm{m}$ and stained with heamatoxylin and eosin.

The total number of follicles per ovary and the size distribution of follicles were determined using the methods of Mandl and Zuckerman (1951). Differential counts of follicles were carried out in one ovary from each rat using the classification which is outlined below and modified from that of Mandl and Zuckerman (1952). Primordial follicles were counted in every tenth section. Growing follicles were counted in every fifth section using the oocyte nucleolus as a marker.

\section{Follicle classification.}

(i) Primordial follicles with a non-growing oocyte : follicle envelope of flattened follicle cells or a combination of flattened follicle cells and cuboidal follicle cells.

(ii) Growing follicles with a growing oocyte : Stage 1 : follicle with a single layer of cuboidal cells ; Stage 2 : follicle with 2 layers of cuboidal cells; Stage 3 : follicle envelope with 3 layers of cuboidal cells; Stage 4 : multilaminar follicle envelope. 
(iii) Growing follicles with a fully-grown oocyte : Stage 5 : follicle envelope with or without lacunae of fluid ; Stage 6 : follicle envelope with antrum.

The rate of exit of primordial follicles from the non-growing pool between day 42 and day 66 was compared in ad libitum-fed rats and starved and refed rats. The line of best fit was obtained by relating Log $N$ of primordial follicle numbers to time since the decline in primordial follicles with age in the rat is approximately exponential (Mandl and Zuckerman, 1951).

Discriminant analysis was carried out on the four groups of animals described above $\left(C_{1}, C_{2}, S, S R\right)$, taking as variables the number of follicles in each of the seven size classes. The differences among the four groups were then examined more closely using multiple comparisons (Student-Newman-Keuls test) associated with a one-way analysis of variance (Miller, 1966).

The distribution and number of follicles with age or treatment was compared using the non-parametric test of Kolmogorov-Smirnov (Massey, 1951).

\section{Results.}

We reported previously that semi-starvation of female prepuberal Wistar rats between 21 and 42 days of age reduces body weight and delays puberty. Moreover, semi-starvation reduces the rate of atresia of non-growing oocytes in primordial follicles, reduces the total number of follicles undergoing the pre-antral stages of growth and reduces the proportion of follicles represented by growing follicles (Lintern-Moore and Everitt, 1978). The present findings confirm this response to reduced food intake (tables 1 and 2) and examine the further response of the ovarian follicular population when starvation is followed by refeeding.

\section{TABLE 1}

The numbers of small, growing, and fotal follicles per ovary (mean \pm SEM) and incidence of corpora lutea in female Wistar strain rats starved $(S)$ or fed ad libifum $\left(C_{1}\right)$ from 21 to 42 days of age or starved from 21 to 42 days of age followed by ad libitum food intake to 66 days of age (SR) or fed an adequate diet from 21 to 66 days of age $\left(C_{2}\right)$

\begin{tabular}{|c|c|c|c|c|c|c|}
\hline Group & $N\left({ }^{1}\right)$ & Age $\left({ }^{2}\right)$ & $\begin{array}{l}\text { Small } \\
\text { follicles }\end{array}$ & $\begin{array}{l}\text { Growing } \\
\text { follicles }\end{array}$ & $\begin{array}{c}\text { Total } \\
\text { follicles }\end{array}$ & $\begin{array}{c}\text { Corpora } \\
\text { Iutea }\end{array}$ \\
\hline $\begin{array}{l}\mathrm{C}_{1} \\
\mathrm{~S} \\
\mathrm{C}_{2} \\
\mathrm{SR}\end{array}$ & $\begin{array}{l}6 \\
6 \\
8 \\
8\end{array}$ & $\begin{array}{l}42 \\
42 \\
66 \\
66\end{array}$ & $\begin{array}{l}4,699 \pm 253 \\
7,120 \pm 345 \\
3,021 \pm 323 \\
5,766 \pm 283\end{array}$ & $\begin{array}{l}586 \pm 23 \\
321 \pm 38 \\
472 \pm 27 \\
642 \pm 40\end{array}$ & $\begin{array}{l}5,285 \pm 254 \\
7,441 \pm 321 \\
3,493 \pm 242 \\
6,408 \pm 316\end{array}$ & $\begin{array}{l}5 / 6 \\
0 / 6 \\
8 / 8 \\
8 / 8\end{array}$ \\
\hline
\end{tabular}

( $\left.{ }^{1}\right)$ Number of animals per group ; $\left({ }^{2}\right)$ age (days) at death.

A. Body and organ weights. - Rats semi-starved from 21 to 42 days of age were allowed ad libitum access to food at 42 days of age (Group SR) until they attained the body weight of ad libitum-fed controls of the same chronological age (Group $\mathrm{C}_{2}$ ). This occurred after 24 days of refeeding at 66 days of age (fig. 1). The age of vaginal open- 


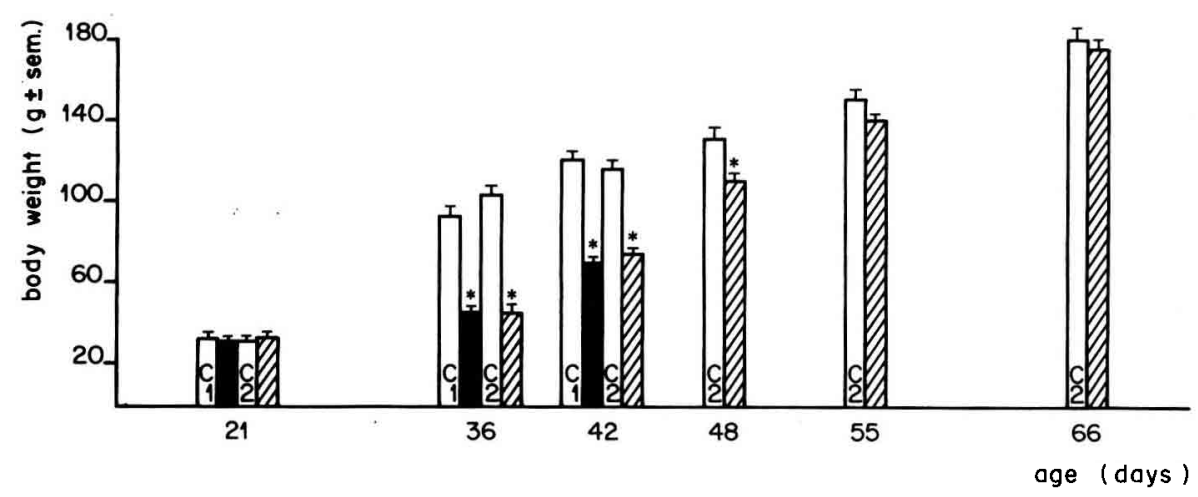

FIG. 1. - Body weights in 4 groups of female Wistar strain rats. Solid bars : food restricted from 21 to 42 days of age. $C_{1}$ : ad libitum food intake from 21 to 42 days of age. Hatched bars : food restricted from 21 to 42 days of age and allowed ad libitum food intake from 42 to 66 days of age. $C_{2}$ : ad libitum food intake from 21 to 66 days of age.

ing was delayed in the refed rats relative to control groups $\left(C_{1}: 38 \pm 1\right.$ days; $C_{2}$ : $39 \pm 2$ days ; $S R: 50 \pm 2$ days, $P<0.001$ ) ; however the body weight at which vaginal opening occurred, although slightly elevated following refeeding ( $S R: 116 \pm 8 \mathrm{~g}$ ), was not statistically different from control values $\left(C_{1}: 111 \pm 6 \mathrm{~g} ; C_{2}: 105 \pm 6 \mathrm{~g}\right)$. Furthermore, uterine and ovarian weights which were depressed in starved rats $(S)$ at 42 days of age relative to ad libitum fed control values $\left(C_{1}\right)$ (uterine weights : $C_{1}$ : $58 \pm 7 \mathrm{mg} ; \mathrm{S}: 25 \pm 7 \mathrm{mg} ; \mathrm{P}<0.05$; ovarian weights : $C_{1}: 30 \pm 2 \mathrm{mg}$; $\mathrm{S}: 19 \pm 2 \mathrm{mg} ; \mathrm{P}<0.05$ ) were restored after refeeding (uterine weights : $C_{2}$ : $133 \pm 15 \mathrm{mg} ; S R: 119 \pm 11 \mathrm{mg} ;$ ovarian weights : $C_{2}: 58 \pm 3 \mathrm{mg} ; S R: 54 \pm 2 \mathrm{mg}$ ).

B. Ovarian follicular population. - Discriminant analysis carried out on the four experimental groups and based on the seven variables (the number of follicles belonging to the seven, defined stages of growth) showed that the following variables allowed the best separation of groups :

a) the number of primordial follicles in conjunction with the number of follicles in stages 5 and 6 ;

b) the number of follicles in stages 1 and 2 (with at most two layers of granulosa cells), and thus at the beginning of growth, in conjunction with the number of follicles in stages 3 and 4 (with three or more layers of granulosa cells).

Age-dependent changes. Between control groups $C_{1}$ at 42 days of age and $C_{2}$ at 66 days of age, the total number of primordial and growing follicles per ovary declined (table 1, fig. 2). The number of growing follicles also altered with age (table 2). By 66 days of age significantly fewer uni and bilaminar follicles (Stages 1 and 2) (fig. 3) were present relative to 42 -days-old values. However tri and multilaminar follicles (Stages 3 and 4) (fig. 3) were significantly more numerous than at 42 days of age.

The increase in the number of vesicular multilaminar and antral follicles (Stages 5 and 6) (fig. 3) was not significant. Apart from the reduction in the total number of 
follicles, there were also significant changes in the proportions of follicles in the different classes (Kolmogorov-Smirnov test ; $P>0.05$ ).

TABLE 2

The numbers of growing follicles (mean \pm SEM) in successive growth compartments in rats starved (S) or fed ad libitum $\left(C_{1}\right)$ from 21 to 42 days of age and rats starved from 21 to 42 days of age and refed ad libitum to 66 days of age (SR) or fed ad libitum from 21 to 66 days of age $\left(C_{2}\right)$

\begin{tabular}{|c|c|c|c|c|c|c|c|c|}
\hline \multirow[b]{2}{*}{ Group } & \multirow[b]{2}{*}{$N$} & \multirow[b]{2}{*}{ Class } & \multicolumn{6}{|c|}{ Follicle classification } \\
\hline & & & 1 & 2 & 3 & 4 & 5 & 6 \\
\hline $\begin{array}{l}C_{1} \\
S \\
C_{2} \\
S R\end{array}$ & $\begin{array}{l}6 \\
6 \\
8 \\
8\end{array}$ & & $\begin{array}{l}228 \pm 15 \\
106 \pm 17 \\
148 \pm 11 \\
206 \pm 29\end{array}$ & $\begin{array}{r}176 \pm 8 \\
73 \pm 12 \\
89 \pm 9 \\
109 \pm 6\end{array}$ & $\begin{array}{r}73 \pm 6 \\
62 \pm 12 \\
91 \pm 5 \\
133 \pm 13\end{array}$ & $\begin{array}{r}67 \pm 3 \\
49 \pm 7 \\
100 \pm 10 \\
143 \pm 14\end{array}$ & $\begin{array}{l}32 \pm 2 \\
23 \pm 2 \\
28 \pm 2 \\
32 \pm 3\end{array}$ & $\begin{array}{r}10 \pm 3 \\
8 \pm 2 \\
16 \pm 3 \\
19 \pm 2\end{array}$ \\
\hline
\end{tabular}

$P>0.05$ (for comparison of distribution of follicles by Kolmogorov-Smirnov test).

$C_{1}$ vs $S$ : significant difference $(P<0.05) ; C_{1}$ vs $C_{2}$ : significant difference ; $S$ vs $S R$ : significant difference ; $C_{2}$ vs $S R$ : non-significant difference.

Treatment-dependent changes. Ovaries from starved rats (Group S) contained significantly more primordial follicles than found in age-matched controls (fig. 2). Refeeding of starved rats (Group SR) to 66 days reduced the numbers of primordial follicles but the total number did not decline to values found in ad libitum-fed controls of the same chronological age (Group $\mathrm{C}_{2}$ ) ; nonetheless the rates of decline in primordial follicle numbers between 42 and 66 days of age were not significantly different between control and starved/starved refed rats.

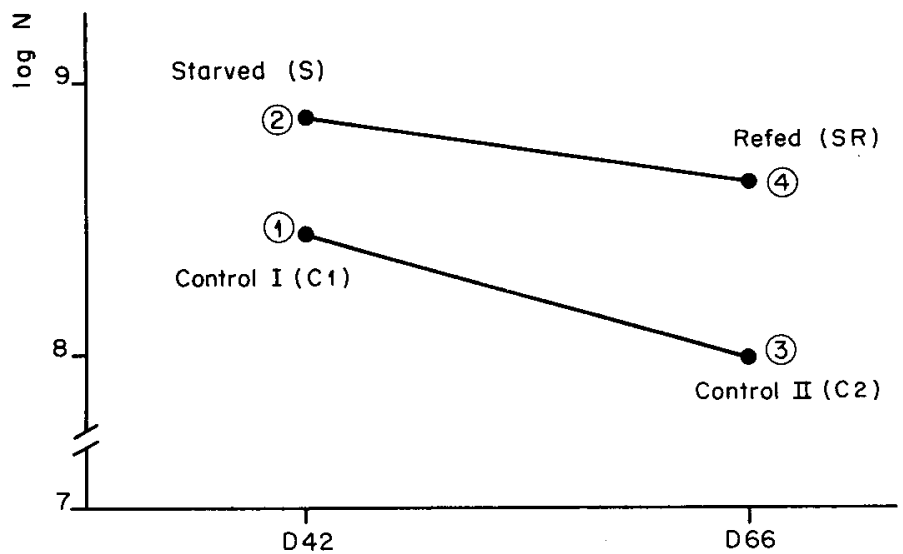

FIG. 2. - The number of primordial follicles per ovary in 4 groups of female Wistar strain rats in relation to age. 1) Control $\left(C_{1}\right)$ ad libitum food intake from day 21 to day 42 . 3) Control $\left(C_{2}\right)$ ad libitum food intake from day 21 to day 66. 2) Food restricted (S) from day 21 to eay 42. 4) Food restricted from day 21 to day 42 and allowed ad libitum food intake from day 42 to day 66 (SR). 
Refeeding increased the number of follicles in stages 1 and 2 compared with those for control group $\mathrm{C}_{2}$. Furthermore, the number of stage 3 and stage 4 follicles, which rose by only 36.4 p. 100 between days 42 and 66 in controls, rose by 148.7 p. 100 in the
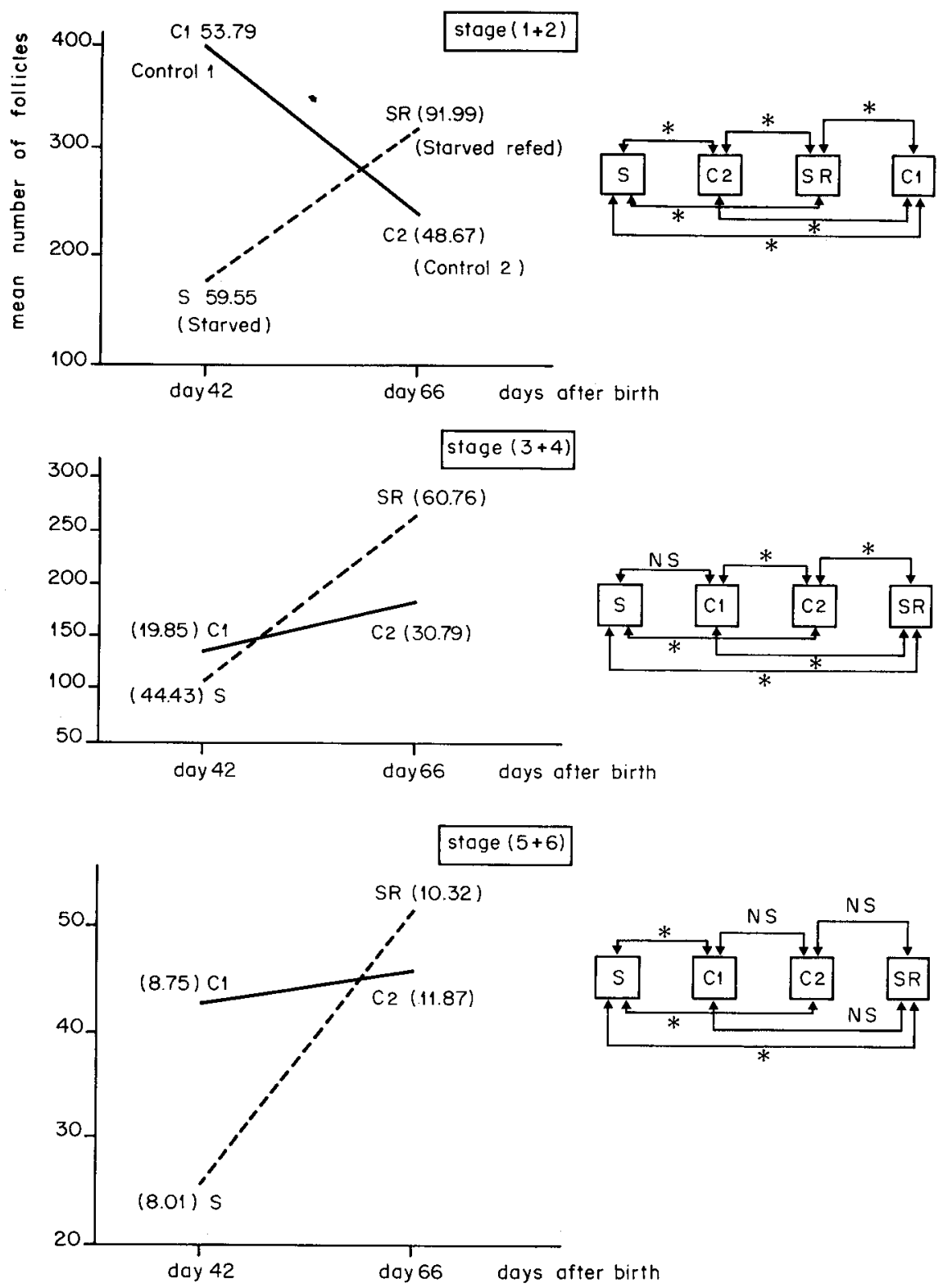

FIG. 3. - Number of follicles of stage $(1+2)$, stage $(3+4)$, stage $(5+6)$ in 4 groups of female Wistar strain rats $\left(C_{1}, C_{2}, S, S R\right)$ (Cf. text). The figure on the right indicates the significance of difference at the 5 p. 100 level between the different groups for each stage of follicle growth, by means of the Newman-Keuls test of comparison. 
treated group (fig. 3). At day 66, there were significantly more stage 3 and 4 follicles in animals of the SR group than in control animals (fig. 2).

Nutritional state also had a considerable effect on the numbers of stage 5 and stage 6 follicles; there were 26.2 p. 100 fewer of these in the starved group than in controls $\left(\mathrm{C}_{1}\right)$ (fig. 3).

Refeeding filled this gap since at day 66 there was no significant difference between groups $\mathrm{C}_{2}$ and SR. Nevertheless the ovaries from refed rats appeared to contain significantly more newly-formed corpora lutea per ovary than did $C_{1}$ or $C_{2}$ ovaries (SR : $\left.10 \pm 1 ; C_{1}: 5 \pm 1 ; C_{2}: 4 \pm 1\right)$.

Furthermore, comparison of the overall distributions of follicles (table 1) revealed no significant difference between control $\left(C_{2}\right)$ and starved/refed (SR) groups (Kolmogorov Smirnov test ; $P<0,05)$.

\section{Discussion.}

Primordial follicle numbers. - A decline, with increasing age, in the numbers of primordial follicles containing non growing oocytes is a recognised developmental charac teristic of the mammalian ovary (Krohn, 1967). The exit of primordial follicles from the finite pool established during perinatal life in the rat represents both atresia within the pool and follicular growth towards ovulation (Zuckerman, 1951). Starvation between 21 and 42 days of age reduced the numbers of follicles undergoing growth and also the rate of atresia of primordial follicles as reported previously (Lintern-Moore and Everitt, 1978). Subsequent refeeding did reduce the numbers of primordial follicles but these remained more numerous than in ad libitum-fed controls. However, accepting that the age-dependent decline in primordial follicle numbers in the rat is exponential (Mandl and Zuckerman, 1952), we find that refeeding re-established the normal rate of exit of follicles from the primordial follicle pool. This was reflected by the presence of more growing follicles in the refed group (SR).

The physiological control of the numbers of primordial follicles in the mammalian ovary is unknown. Other treatments are known to lead to a decline in the rate of atresia of oocytes, notably hypophysectomy (rat : Paesi, 1949 ; mouse : Jones and Krohn, 1961), congenital hypopituitarism (dwarf mouse : Howe et al., 1978) and athymia in the neonate (nude mouse : Lintern-Moore and Pentelouris, 1976 ; thymectomised rat : Lintern-Moore and Pentelouris, 1976 ; thymectomised rat : Lintern-Moore, 1977). Although in all cases, as in starvation, the release pf pituitary hormones is depressed, this is also accompanied by a reduction in the rate of growth and/or metabolic rate (see Everitt and Porter, 1976 ; Pantelouris and Lintern-Moore, 1978). Thus any direct involvment of specific pituitary hormones in the control of the numbers of primordial follicles remains equivocal.

Growing follicles. - In the developing ovary of both the rat (Knudsen ef al., 1979) and the mouse (Krarup ef al., 1961), the numbers of follicles undergoing growth is proportional to the number of primordial follicles. As the number of primordial follicles declines with increasing age so, too, the numbers of growing follicles decline. In addition, an age-dependent shift in the numbers of growing follicles gives rise to proportionally more multilaminar and antral follicles in the older ovary. Knudsen ef al. (1979) 
suggest that this change in the size distribution of follicles in the rat is an important function of sexual maturation.

In the present study the relationship between the numbers of growing and primordial follicles was disrupted by starvation, there being more primordial follicles and fewer growing follicles. Refeeding restored this proportionality to control values. Although the total numbers of growing follicles in the refed group exceeded control values at 66 days of age, the size distribution of follicles within each growth compartment was not different from control values, both groups exhibiting proportionally larger follicles than at 42 days of age.

The presence of more multilaminar follicles in the starved/refed group may result from the reported increase in $\mathrm{FSH} / \mathrm{LH}$ levels following starvation and refeeding in the rat (Welschen, 1973 ; Campbell ef al., 1977). Further it could be suggested that the husbandry practice of semi-starvation followed by refeeding, termed flushing (Casida, 1963), which increases ovulation rate in domestic animals depends upon the follicular response to nutritional change reported here. Printz and Greenwald (1970) found in the starved/refed hamster significantly more ovulations. Lamond and Bindon (1969) have reported in both the mouse and sheep that a reduced plane of nutrition followed by refeeding results in a greater ovulatory response to exogenous gonadotrophins. In the present study not only did ovaries of starved/refed rats contain more growing follicles but also more corpora lutea were present at 66 days of age. We suggest that a starvation/refeeding regime may cause a pseudo/superovulatory response from the ovary which is permitted by the presence of more growing follicles coupled with an elevated level of endogenous gonadotrophins (Campbell ef al., 1977).

\section{Conclusion.}

Thus refeeding following a period of starvation re-established the normal rate of exit of primordial follicles from the finite pool and restored the size distribution of growing follicles but the absolute number of follicles continued to exceed control values. These data illustrate the stability of follicular processes and reveal the potential lability of primordial and growing follicle numbers. The response of the ovary to starvation in terms of conservation of germ cells coupled with the inhibition of ovulation may, in species subjected to reduced food intake in the natural environment, provide an admirable survival mechanism. Not only may the reduction in oestrogen production, mirrored in reduced uterine weight during starvation, prolong the functional life of the hypothalamus (Aschheim, 1976) but also sufficient germ cells may be conserved to account for the reported extension of reproductive life in intermittently starved animals (Visscher ef al., 1962 ; Berg, 1960 ; Holeckova and Chvapil, 1965). The response of the ovary to starvation/refeeding described here may permit a starved animal to capitalise to the maximum in reproductive terms during a temporarily improved plane of nutrition.

Finally, starvation and refeeding appears to provide for the first time an experimental model in which the age-dpendent loss of oocytes from the ovary (occurring not only in mammals but also other vertebrate species (Krohn, 1967)) can be experimentally manipulated and therefore studied. 
Acknowledgements. - This study was supported in part by a grant to SL-M from the Clive and Vera Ramaciotti Foundations, Australia, Robyn Carr provided expert technical assistance.

Résumé. Une réduction du niveau d'alimentation de 50 p. 100 chez des femelles de rat Wistar âgées de 21 jours et jusqu'à 42 jours empêche l'ovulation et modifie la distribution de la taille des follicules et leur nombre. Le taux d'atrésie des follicules primordiaux à oocyte quiescent est réduit, et le nombre de ces follicules est donc plus important. Le nombre des follicules qui démarrent leur croissance est réduit.

Des rats dont on a réduit l'alimentation jusqu'à 42 jours sont ensuite normalement nourris jusqu'à l'âge de 66 jours. On observe chez ces animaux une puberté retardée. Les nombres de follicules primordiaux à ovocyte quiescent est réduit mais reste significativement supérieur à celui des témoins âgés de 66 jours. La réalimentation entraîne une augmentation du nombre de follicules en croissance mais dans la même fourchette de taille que chez les animaux témoins de même âge.

On discute enfin des relations possibles entre l'ovaire et l'hypophyse et des modifications entraînées par la sous-alimentation suivie d'une alimentation normale. On discute également de la plasticité potentielle de la population des follicules aux conditions d'environnement.

\section{References}

ASCHHEIM P., 1976. Aging in the hypothalamic-hypophyseal ovarian axis in the rat, 376-418. in A. V. EVERITT, J. A. BURGESS, Hypothalamus, pifuitary and aging. Thomas, Springfield, III.

BERG B. N., 1960. Nutrition and longevity in the rat. I. Food intake in relation to size, health and longevity. J. Nutr., 71, 242.

CAMPBELL G. A., KURCZ M., MARSCHALL S., MEITES J., 1977. Effects of starvation in rats on serum levels of Follicle Stimulating Hormone, Luteinizing Hormone, Thyrotropin, Growth Hormone and Prolactin : response to LH-releasing hormone and Thyrotropin-releasing hormone. Endocrinology, 100, 580-587.

CASIDA L. E., 1963. The level of fertility in the female as influenced by feed level and energy intake. Proc. 6th int. Congr. Nutr., Edinburgh, 366-375.

DICKERSON J.W. T., GRESHAM G. A., MCCANCE R. A., 1964. The effect of undernutrition and rehabilitation on the development of the reproductive organs : pigs. J. Endocrinol., 29, 111-118.

EVERITT A. V., PORTER B., 1976. Nutrition and aging, 570-613. In A. V. EVERITT, J. A. BURGESS, Hypothalamus, pituitory and aging, Thomas, Springfield, III.

JONES E. C., KROHN P. L., 1961. The effect of hypophysectomy and age changes in the ovaries of mice. J. Endocrinol., 213, 497-509.

HOLECKOVA E., CHVAPIL M., 1965. The effect of intermittent feeding and fasting and of domestication on biological age in the rat. Gerontologia, 11, 96-104.

HOWE E., LINTERN-MOORE S., MOORE G. P. M., HAWKINS J., 1978, Ovarian development in hypopituitary Snell dwarf mice. The size and composition of the follicle population Biol. Reprod., 19, 959-964.

KNUDSEN J. F., LOSTOFF A., MANESH V. R., 1979. Correlation of serum gonadotrophins, ovarian and uterine histology in immature and prepubertal rats. Anat. Rec., 180, 497-508.

KRARUP T., PEDERSEN T., FABER M., 1969. Regulation of oocyte growth in the mouse. Nature (Lond.), 224, 187-188.

KROHN P. L., 1967. Factors influencing the number of oocytes in the ovary. Arch. Anat. microsc. Morphol. exp., 56, Suppl. 3-4, 154.

LAMMING G. E., 1966. Nutrition and the endocrine system. Nutr. Abstr. Rev., 36, 1-13.

LAMOND D. R., BINDON B. M., 1969. Effect of nutrient intake on ovulation in mice and sheep. Biol. Reprod., 1, 264-271.

LINTERN-MOORE S., 1974. Effect of athymia on the initiation of follicular growth in the rat ovary. Biol. Reprod., 17, 155-161. 
LINTERN-MOORE S., 1978a. Initiation of follicular growth in the infant mouse ovary by exogenous gonadotrophin. Biol. Reprod., 17, 635-639.

LINTERN-MOORE S., 1978b. A differential effect of protein and calorie deficiency on ovarian follicular growth in the sow. Mech. Ageing Dev., 7, 199-207.

LINTERN-MOORE S., EVERITT A. V., 1978. The effect of restricted fooknta de on the size and composition of the ovarian follicle population in the Wistar rat. Biol. Reprod., 19, 688-691.

LINTERN-MOORE S., PANTERLOURIS E. M., 1976. Ovarian development in athymic nude mice. $V$. The effects of PMSG upon the numbers and growth of follicles in the early juvenile ovary. Mech. Ageing Dev., 5, 259-265.

MANDL A., ZUCKERMAN S., 1961. The relationship of age to the number of oocytes. J. Endocrinol., 7, 190-193.

MANDL A., ZUCKERMAN S., 1952. The growth of the oocyte and follicle in the adult rat. J. Endocrinol., 8, 126-132.

MASSEY F. J., 1951. The Kolmogorov Smirnov test for goodness of fit. J. amer. Stat. Ass., 46, 68-128.

MAULÉON P., 1969. Oogenesis and folliculogenesis, 187-215. In H. H. COLE, P. T. CUPPS, Reproduction in domestic animals, 2nd Ed. Acad. Press, N. Y. \& Lond.

MILLER R. G., 1966. Simulfoneous statistical inference. McGraw and Hill, New York.

PAESI F. J. A., 1949. The influence of hypophhsectomy and of subsequent treatment with chorionic gonadotrophins on follicles of different sizes in the ovary of the rat. Acto endocr., 3, 89-104.

PANTELOURIS E. M., LINTERN-MOORE S., 1978. Physiological studies in the nude mouse, 82-97, In J. FOGH, B. GIOVANELLA, The nude mouse in experimental and clinical research. Acad. Press, N. Y.

PETERS H., 1969. The development of the mouse ovary from birth to maturity. Acta endocr., 62, 98-116.

PRINTZ R. H., GREENWALD G. S., 1970. Effect of starvation on follicular development in the cyclic hamster. Endocrinology, 86, 290-295.

VISSCHER M. B., KING J. K., LEE Y. C. P., 1952. Further studies of age and dief upon reproductive senescence in strain A female mice. Am. J. Physiol., 170, 72-98.

WELSCHEN R., 1973. Amounts of gonadotrophins required for normal follicular growhf in hypophysectomised adult rats. Acta endocr., 72, 137-155.

WIDDOWSON E. M., MAVOR W. O., MCCANCE R. A., 1964. The effect of undernutrition and rehabilitation on the development of reproductive organs : rats. J. Endocrinol., 29, 119-126.

ZUCKERMAN S., 1951. The numbers of oocytes in the mature ovary. Rec. Progr. Horm. Res., 6, 63-109. 